\title{
Pengelompokkan Provinsi di Indonesia Berdasarkan Tingkat Kemiskinan Menggunakan Analisis Hierarchical Agglomerative Clustering
}

\author{
(Indonesian Province Grouping Based on Poverty Level Using Hierarchical Agglomerative \\ Clustering Analysis)
}

\author{
Edy Widodo ${ }^{1 *}$, Putri Ermayani ${ }^{2}$, Latifah Nur Laila ${ }^{3}$, Asdan Tri Madani ${ }^{4}$ \\ ${ }^{1,2,3,4}$ Universitas Islam Indonesia \\ JL. Kaliurang Km 14.5 Yogyakarta \\ E-mail: edywidodo@uii.ac.id
}

\begin{abstract}
ABSTRAK
Sebagai permasalahan yang kompleks dan multidimensional, kemiskinan menjadi prioritas pembangunan. Setiap negara memiliki faktor penyebab kemiskinan yang beragam, diantaranya disebabkan oleh Sars-Cov-2 sepanjang tahun 2020. Pengaruhnya berupa kenaikan tingkat kemiskinan pada provinsi-provinsi di Indonesia. Sehingga Dalam usaha pengentasan kemiskinan dapat melakukan pengelompokkan tingkat kemiskinan provinsi di Indonesia untuk mengetahui provinsi yang layak mendapatkan prioritas penanganan. Penelitian terkait telah banyak dilakukan hanya berfokus pada suatu provinsi dan belum secara menyeluruh. Pada penelitian ini dilakukan analisis menggunakan seluruh provinsi di Indonesia serta indikator kemiskinan yang lebih lengkap yaitu indeks keparahan kemiskinan, indeks kedalaman kemiskinan, angka melek huruf, rata-rata lama sekolah, harapan lama sekolah, tingkat pengangguran terbuka, dan persentase penduduk miskin. Pengelompokkan dilakukan dengan metode analisis hierarchical agglomerative clustering. Hasil penelitian diperoleh 3 cluster tingkat kemiskinan yaitu cluster 1 merupakan tingkat rendah dengan anggota 25 provinsi, cluster 2 atau tingkat sedang sebanyak 7 provinsi, dan cluster 3 dengan tingkat tinggi sebanyak 2 anggota.
\end{abstract}

Kata kunci: Covid-19, Hierarchical Agglomerative Clustering, Indikator Kemiskinan, Tingkat Kemiskinan

\begin{abstract}
As a complex and multidimensional problem, poverty is a development priority. Each country has various poverty factors, including sars-cov-2 throughout 2020. The effect is in the form of an increase in poverty rates in the provinces in Indonesia. So that in the effort of poverty alleviation can group the provincial poverty rate in Indonesia to find out which provinces deserve priority handling. Much of the research has been done focusing only on a province and not as a whole. The study was analyzed using all provinces in Indonesia as well as more complete indicators of poverty severity index, poverty depth index, literacy rate, average length of school, old school expectations, open unemployment rate, and percentage of poor population. Grouping is done by hierarchical agglomerative clustering analysis method. The results of the study obtained 3 clusters of poverty levels, namely cluster 1 is a low level with members of 25 provinces, cluster 2 or medium level as many as 7 provinces, and cluster 3 with a high level of 2 members.
\end{abstract}

Keywords: Covid-19, Hierarchical Agglomerative Clustering, Poverty Indicators, Poverty Level

\section{PENDAHULUAN}

Kemiskinan merupakan ketidakmampuan dalam pemenuhan kebutuhan primer seperti makanan, pakaian, tempat berlindung, pendidikan, dan kesehatan. Berdasarkan Survei Ekonomi Nasional September 2020, Badan Pusat Statistika merilis data terkait kemiskinan yang menunjukkan kenaikan sebesar $10.19 \%$ dimana mengalami peningkatan sebesar $0.41 \%$ dari persentase penduduk miskin pada bulan Maret 2020. Kemiskinan yang terjadi di Indonesia merupakan masalah yang menjadi prioritas pembangunan karena sangat kompleks dan bersifat multidimensional. Terwujudnya masyarakat yang adil dan makmur sebagai salah satu cita-cita bangsa dapat diwujudkan dengan pengentasan kemiskinan yang terjadi di Indonesia (Royat, 2015).

Setiap negara memiliki beragam faktor penyebab kemiskinan, diantaranya pada masa pandemi yang diakibatkan oleh Sars-Cov-2 (Bullard J, 2020). Awal mula kasus terkonfimasi Covid-19 di Indonesia pada 2 Maret 2020 dan terus mengalami fluktuasi pada jumlah pasien terkonfirmasi positif Covid-19 hingga kuartal akhir 2020 yang berpengaruh pada berbagai aspek kehidupan, contohnya tingkat kemiskinan yang mengalami kenaikan. Pandemi Covid-19 berdampak pada kemiskinan dan ketimpangan yang terjadi di Indonesia terus pada tren meningkat. Jumlah penduduk usia kerja sebanyak 203,97 juta orang, dengan total terdampak 
pandemi sebesar 14,28\% atau 29,12 juta orang menjadi penyebab meningkatnya kemiskinan (BPS, 2020). Peningkatan jumlah miskin mengalami peningkatan dibandingkan sebelum adanya pandemi sekitar 1,16 juta hingga 3,78 juta orang. Penyebab utama kemiskinan yang terjadi di Indonesia adalah kurangnya pendidikan dan kualitas sumber daya manusia (SDM) yang menyebabkan tingginya angka pengangguran terutama cluster kemiskinan daerah pedesaan.

Kemiskinan yang tinggi akan menyebabkan beberapa dampak sosial salah satunya adalah tingginya angka pengangguran. Masyarakat yang tidak memiliki pekerjaan, besar kemungkinan akan mencari cara lain untuk mendapatkan kebutuhan harian meskipun dengan cara yang tidak legal. Hal tersebut tentunya akan meningkatkan kasus kriminalitas yang terjadi di Indonesia. Sehingga diperlukan peninjauan lebih lanjut untuk dapat mengatasi masalah kemiskinan di Indonesia supaya tidak menimbulkan permasalahan lainnya. Upaya yang dapat dilakukan dalam pengentasan kemiskinan yaitu mengetahui daerah dengan tingkat kemiskinan tertinggi, sedang atau rendah agar pemerintah dapat menetapkan skala prioritas dalam menanggulangi kemiskinan. Pengelompokan tingkat kemiskinan di Indonesia dapat menjadi referensi bagi pemerintah dalam merancang kebijakan yang sesuai berdasarkan karakteristik kemiskinan yang dimiliki oleh setiap provinsi. Hasil pengelompokkan dapat membantu upaya penanganan yang dilakukan akan tepat sasaran sehingga perekonomian masyarakat Indonesia dapat lebih merata.

Penelitian mengenai pengelompokkan kemiskinan pernah dilakukan oleh F. Fajriani pada tahun 2019 menggunakan indikator indeks kedalaman kemiskinan dan indeks keparahan kemiskinan pada masing-masing kabupaten/kota. Pada penelitian tersebut dilakukan analisis cluster kemiskinan di Provinsi Sulawesi Selatan dengan hasil penelitian berupa 2 cluster kemiskinan. Penelitian Debrina vita ferezagia pada tahun 2018 menggunakan analisis multivariat non hierarki dengan 3 indikator kemiskinan yaitu indeks keparahan kemiskinan, indeks kedalaman kemiskinan, dan presentase penduduk miskin. Hasil penelitian dengan analisis non hierarki cluster mengelompokan provinsi di Indonesia menjadi 3 kelompok yaitu provinsi miskin (cluster 1), sedang (cluster 2) dan tidak miskin (cluster 3). Meskipun sudah banyak riset terkait dengan indikator tingkat kemiskinan namun masih dilakukan secara parsial dan masih jarang yang dilakukan secara menyeluruh. Pada penelitian ini dilakukan penelitian dengan melibatkan indikator kemiskinan yang lebih lengkap yaitu Indeks Keparahan Kemiskinan, Indeks Kedalaman Kemiskinan, Angka Melek Huruf (AMH), Rata-Rata Lama Sekolah (RLS), Harapan Lama Sekolah (HLS), Tingkat Pengangguran Terbuka (TPT), dan Persentase Penduduk Miskin (PPM).

Pengelompokkan daerah yang memiliki karakteristik yang sama dapat dilakukan dengan analisis cluster. Analisis cluster akan mengklasifikasi provinsi di Indonesia yang memiliki sifat mirip (paling dekat kesamaannya) dalam cluster yang sama. Tujuan dari penelitian ini yaitu mengetahui kondisi tingkat kemiskinan berdasarkan faktor yang memperngaruhinya, mengetahui pengelompokkan tingkat kemiskinan, dan mengetahui karakteristik setiap cluster tingkat kemiskinan di Indonesia saat pandemi Covid-19. Analisis cluster dibagi menjadi 2 yaitu analisis cluster hirarki dan analisis cluster non hirarki. Pada penelitian ini akan digunakan analisis cluster hirarki, data yang digunakan akan membentuk hirarki atau tingkatan tersendiri sehingga mempermudah dalam interpretasi. Penggunaan metode cluster hirarki dalam penelitian ini adalah metode agglomerative dengan 4 sub metode yaitu single linkage, complete linkage, average linkage, dan metode ward's.

\section{METODE}

\section{Analisis Clustering}

Analisis cluster merupakan elemen dari proses data mining yang berfungsi mengelompokkan obyek menjadi sebuah cluster data. Cluster merupakan sekelompok obyek data yang mempunyai kesamaan dalam cluster yang sama. Analisis cluster berfungsi mengenali sekelompok obyek dengan kesamaan dan karakteristik yang mampu dibedakan terhadap cluster lainnya (Dani, Wahyuningsih, \& Rizki, 2019).

Menurut Santoso (2017), analisis cluster akan menghasilkan beberapa cluster. Sementara menurut Supranto (2004), analisis cluster adalah teknik untuk mengelompokkan obyek pada cluster yang cukup homogen disebut cluster, sehingga objek yang berbeda akan dikelompokkan dalam cluster yang lain. Analisis cluster memiliki beberapa konsep seperti:

1. aglomeration schedule memberikan jadwal informasi obyek yang akan dikumpulkan pada proses clustering hirarki.

2. Kedudukan cluster yang menunjukkan setiap obyek yang menjadi anggota suatu cluster. 
3. dendogram sebagai penyajian hasil analisis cluster. Garis tegak pada dendogram merepresentasikan gabungan anggota suatu cluster, sedangkan garis pada skala menunjukkan jarak antar gabungan cluster.

4. koefisien agglomerative merupakan nilai yang digunakan dalam penentuan kebaikan hasil clustering. Nilai koefisien mendekati 1 artinya pengelompokkan semakin baik atau semakin kuat.

5. asumsi cluster yang pertama menurut Santoso (2017) adalah sampel yang digunakan dapat mewakili populasi atau dapat dikatakan representatif. Ketentuan jumlah sampel representatif memang tidak ada, tetapi tetap membutuhkan sampel yang cukup besar untuk keakuratan proses clustering. (Ningrat, Maruddani, \& Wuryandari, 2016)

6. asumsi cluster kedua yang harus dipenuhi adalah multikolinearitas dimana menunjukkan hubungan linear diantara beberapa atau semua variabel penelitian yang digunakan. Dalam pengujiannya multikolinearitas diketahui dari nilai Variance Inflation Factor (VIF), apabila nilai VIF lebih dari 10 maka terdapat gejala multikolinearitas. Sedangkan nilai VIF yang kurang dari 10 menandakan tidak terdapat gejala multiokolinearitas (Prabowo, Nisa, Faisol, \& Setiawan, 2020). Apabila terjadi multikolinearitas akan dilakukan pengukuran jarak dengan menggunakan metode jarak Mahalanobis. Sedangkan ketika tidak terjadi multikolinearitas, maka digunakan perhitungan jarak dengan menggunakan metode jarak Euclidean (Rahmawati, 2013).

a. Jarak Mahalanobis, digunakan jika data terjadi korelasi. Menurut Durak (2001) dalam (Rahmawati, 2013), perhitungan jarak Mahalanobis antara dua sampel X dan Y dari suatu variabel acak dirumuskan sebagai berikut :

$$
\begin{aligned}
& d(x, y)=\sqrt{(y-x)^{T} \sum^{-1}(y-x)} \\
& \text { dengan : } \\
& d(\boldsymbol{x}, \boldsymbol{y})=\text { jarak mahalanobis } \\
& x \quad=\text { vektor untuk } x \\
& \boldsymbol{y}=\text { vektor } y \\
& \Sigma=\text { matriks varian kovarian } .
\end{aligned}
$$

b. Jarak Euclidean, digunakan ketika tidak terjadi korelasi pada data. Rumus yang digunakan pada jarak Euclidean adalah sebagai berikut:

$$
d(y, x)=\sqrt{\sum_{k=1}^{n} \quad\left(y_{k}-x_{k}\right)^{2}} ; k=1,2,3, \ldots, n
$$

dengan:

$d(x, y)=$ kuadrat jarak Euclidean antar obyek pada y dengan obyek pada $\mathrm{x}$

$y_{k} \quad=$ nilai dari obyek y pada variabel ke-k

$x_{k} \quad=$ nilai dari obyek $\mathrm{x}$ pada variabel ke-k

\section{Hirarki Clustering}

Hirarki cluster merupakan pengembangan dari suatu hirarki atau struktur mirip pohon bercabang. Pengelompokan hirarki memiliki algoritma dengan melakukan pembuatan $m$ cluster yang terdiri atas 1 obyek dari suatu data. Selanjutnya antara satu cluster digabung dengan cluster lain yang memiliki jarak terdekat (Widyawati, Saptomo, \& Utami, 2020). Tahapan tersebut berlanjut hingga $m$ cluster yang terdiri atas satu objek menjadi satu cluster dengan anggota $m$ objek.

Algoritma hirarki clustering dibagi menjadi dua, yaitu divisive dan agglomerative. Metode hirarki divisive bermula dari satu cluster yang terdiri atas semua obyek yang ada. Tahap berikutnya adalah pemisahan cluster yang memiliki ketidakmiripan yang cukup besar hingga terbentuk cluster yang lebih kecil. Pemisahan tersebut dilakukan hingga jumlah cluster yang diinginkan telah tercapai.

\section{Agglomerative Clustering}

Hirarki agglomerative clustering merupakan metode hirarki clustering berkarakter bottom-up yang berupa penggabungan $\mathrm{n}$ buah cluster hingga terbentuk dalam satu cluster. Metode tersebut menetapkan masingmasing obyek pada data merupakan satu cluster (atomic cluster) (Febuariyanti \& Winarko, 2010).

a. $\quad$ Single Linkage

Merupakan metode yang mendasarkan jarak atau kesamaan antara pasangan dari obyek penelitian, cluster terbentuk berdasarkan setiap obyek yang memiliki jarak terdekat atau kemiripan terbesar. Perhitungan yang dilakukan adalah mencari jarak terdekat dalam $D=\left\{d_{i k}\right\}$ dan obyek-obyek yang bersesuaian dilakukan penggabungan misalnya, $U$ dan $V$, untuk memperoleh cluster (UV) (Dani, 
Wahyuningsih, \& Rizki, 2019). Metode single linkage memberikan hasil jika cluster digabungkan menurut jarak paling dekat antar obyek (Salton, 1989) dengan rumus:

$d_{(U V) W}=\left\{d_{U V}, d_{V W}\right\}$

dengan :

$\left\{d_{U V}, d_{V W}\right\}=$ jarak terpendek antar cluster.

b. Average Linkage

Menurut Dani, Wahyuningsih, \& Rizki (2019), average linkage dilakukan dengan menghitung ratarata jarak dari semua pasangan obyek dimana satu anggota dari pasangan tersebut adalah bagian setiap cluster. Perhitungan matriks jarak $D=\left\{d_{i k}\right\}$ dilakukan untuk mendapatkan obyek-obyek dengan kemiripan terbesar misalnya $U$ dan $V$. Obyek obyek tersebut dilakukan penggabungan yang membentuk cluster $(U V)$. Selanjutnya dilakukan perhitungan jarak antara $(U V)$ dan cluster $W$ yang lain. Metode average linkage merupakan penyatuan jarak menurut rata-rata antar pasangan obyek setiap himpunan dengan perhitungan:

$d_{(U V) W}=$

$\frac{\sum_{i} \quad \sum_{k} d_{i k}}{N_{(U V)} N_{W}}$

dengan :

$d_{i k} \quad=$ jarak antara obyek $i$ dalam cluster $(U V)$ dan obyek $k$ dalam cluster $W$

$N_{(U V)}=$ banyak item dalam cluster $(U V)$

$N_{W} \quad$ = banyak item dalam cluster $W$.

c. Complete Linkage

Menurut (Wahyuningsih, Rizki, \& Dani, 2019) metode complete linkage mendasarkan jarak terjauh antar objek. Jarak antar cluster merupakan hasil perhitungan obyek yang memiliki jarak terjauh. Perhitungan dimulai dengan menghitung nilai terkecil dalam $D=\left\{d_{i j}\right\}$ dan obyek-obyek yang bersesuaian akan digabungkan, misalnya $U$ dan $V$, untuk memperoleh cluster $(U V)$. Langkah selanjutnya dari algoritma yang dijelaskan yaitu, jarak antara $(U V)$ dan cluster lain W. Metode complete linkage terjadi saat cluster digabungkan menurut jarak antar anggota terjauh (similaritas terkecil) dengan rumus: $d_{(U V) W}=\left\{d_{U V}, d_{V W}\right\}$

d. $\quad$ Metode Ward

Metode Ward merupakan metode hirarki clustering bersifat agglomerative dalam mendapatkan cluster dengan varian internal terkecil. Algoritma agglomerative berupa pengelompokan hirarki yang berawal dari setiap obyek dengan cluster yang berbeda. Pembentukan cluster dilakuakn dengan menggabungkan obyek menjadi sebuah cluster yang memiliki semakin banyak obyek sebagai anggotanya(Oktavia, 2013). Sum Square Error (SSE) merupakan ukuran yang digunakan dengan rumus mentukan jarak berikut :

$S S E=\sum_{i=1}^{n} \quad\left(x_{i}-\underline{x}\right)\left(x_{i}-\underline{x}\right)$

dengan :

$n \quad$ = banyaknya obyek,

$x_{i} \quad=$ obyek ke $1,2,3, . ., \mathrm{n}$,

$\underline{x}=$ rata-rata dalam cluster .

\section{Data dan Sumber Data}

Penelitian ini menggunakan data populasi tentang kemiskinan tahun 2020 bersumber dari Badan Pusat Statistik (BPS) pada laman bps.go.id yang diunduh pada tanggal 24 Maret 2021. Data yang digunakan adalah faktor kemiskinan di Indonesia pada tahun 2020, berupa data indeks kedalaman kemiskinan, indeks keparahan kemiskinan, angka melek huruf, rata-rata lama sekolah, harapan lama sekolah, tingkat pengangguran terbuka, persentase penduduk miskin.

\section{Definisi Operasional Variabel}

Variabel penelitian merupakan segala sesuatu yang akan menjadi objek pengamatan penelitian. Variabel yang digunakan dalam penelitian ini adalah sebagai berikut. 
Tabel 1. Definisi Operasional Variabel Penelitian

\begin{tabular}{|c|c|c|c|}
\hline No & Variabel & Definisi Operasional Variabel & Satuan \\
\hline 1 & $\begin{array}{l}\text { Indeks Keparahan } \\
\text { Kemiskinan }\end{array}$ & $\begin{array}{l}P_{2}=\frac{1}{n} \sum_{i=1}^{q} \quad\left[\frac{z-y_{i}}{z}\right]^{2} \ldots \ldots \ldots \ldots \ldots \ldots \ldots \ldots \ldots \ldots \ldots \ldots \\
\text { dengan : } \\
P_{2} \quad=\text { indeks keparahan kemiskinan } \\
\mathrm{z} \quad=\text { garis kemiskinan } \\
y_{i} \quad=\text { rata-rata pengeluaran perkapita sebulan penduduk yang } \\
\text { berada di bawah garis kemiskinan } y_{i}<\mathrm{z} \\
\mathrm{q} \quad=\text { banyaknya penduduk yang berada di bawah garis } \\
\text { kemiskinan } \\
\mathrm{n} \quad=\text { jumlah penduduk }\end{array}$ & - \\
\hline 2 & $\begin{array}{l}\text { Indeks Kedalaman } \\
\text { Kemiskinan }\end{array}$ & $\begin{array}{l}P_{1}=\frac{1}{n} \sum_{i=1}^{q} \quad\left[\frac{z-y_{i}}{z}\right] \ldots \ldots \ldots \ldots \ldots \ldots \ldots \ldots \ldots \ldots \ldots \ldots \ldots \ldots \\
\text { dengan : } \\
P_{1} \quad=\text { indeks kedalaman kemiskinan }\end{array}$ & - \\
\hline 3 & $\begin{array}{l}\text { Angka Melek Huruf } \\
(\mathrm{AMH})\end{array}$ & $\begin{array}{l}A M H_{15+}^{t}=\frac{M H_{15+}^{t}}{P_{15+}^{t}} \times 100 \ldots \ldots \ldots \ldots \ldots \ldots(9) \\
\text { dengan : } \\
A M H_{15+}^{t}=\text { angka melek huruf usia } 15 \text { tahun keatas pada tahun ke- } \\
\mathrm{t} \\
M H_{15+}^{t}=\text { jumlah penduduk usia } 15 \text { tahun keatas yang dapat } \\
\text { membaca dan menulis } \\
P_{15+}^{t}=\text { jumlah penduduk usia } 15 \text { tahun keatas }\end{array}$ & Persentase $(\%)$ \\
\hline 4 & $\begin{array}{l}\text { Rata-Rata Lama } \\
\text { Sekolah (RLS) }\end{array}$ & $\begin{array}{l}R L S=\frac{1}{n} \times \sum_{i=1}^{n} \quad x_{i} \ldots \ldots \ldots \ldots \ldots \ldots \ldots \ldots \ldots \\
\text { dengan: } \\
\text { RLS = rata-rata lama sekolah penduduk usia } 25 \text { tahun ke atas } \\
x_{i}=\text { lama sekolah penduduk ke-I yang berusia } 25 \text { tahun } \\
\mathrm{n}=\text { jumlah penduduk usia } 25 \text { tahun ke atas }\end{array}$ & Tahun \\
\hline 5 & $\begin{array}{l}\text { Harapan Lama } \\
\text { Sekolah (HLS) }\end{array}$ & $\begin{array}{l}H L S_{a}^{t}=F K \times \sum_{i=a}^{n} \quad \frac{E_{i}^{t}}{P_{i}^{t}} \ldots \ldots \ldots \ldots \ldots \ldots \ldots . . .(11) \\
\text { dengan: } \\
H L S_{a}^{t}=\text { harapan lama sekolah pada umur a di tahun } \mathrm{t} \\
E_{i}^{t}=\text { jumlah penduduk usia I yang bersekolah pada tahun } \mathrm{t} \\
\mathrm{i}=\text { usia }(\mathrm{a}, \mathrm{a}+1, \ldots, \mathrm{n}) \\
\mathrm{FK}=\text { faktor koreksi }\end{array}$ & Tahun \\
\hline 6 & $\begin{array}{l}\text { Tingkat } \\
\text { Pengangguran } \\
\text { Terbuka (TPT) }\end{array}$ & $\begin{array}{l}T P T=\frac{a}{b} \times 100 \% \ldots \ldots \ldots \ldots \ldots \ldots \ldots(12) \\
\text { dengan: } \\
\mathrm{a}=\text { jumlah pengangguran } \\
\mathrm{b}=\text { jumlah angkatan kerja }\end{array}$ & Persentase $(\%)$ \\
\hline 7 & $\begin{array}{l}\text { Persentase } \\
\text { Penduduk Miskin } \\
\text { (PPM) }\end{array}$ & $P_{\propto}=\frac{1}{n} \sum_{i=1}^{q} \quad\left[\frac{z-y_{i}}{z}\right]^{\propto} \ldots \ldots \ldots \ldots \ldots \ldots \ldots . . . . .(13)$ & Persentase $(\%)$ \\
\hline
\end{tabular}

\section{Tahapan Penelitian}

Metode penelitian ini menggunakan analisis cluster dengan metode agglomerative clustering, berikut adalah tahapan penelitian yang dilakukan:

1. melakukan analisis deskriptif;

2. melakukan pengujian asumsi representatif dan multikolinearitas;

3. menentukan metode cluster terbaik dengan membandingkan nilai koefisien agglomerative setiap metode;

4. melakukan penghitungan jarak objek dengan pemilihan metode berdasarkan pengujian multikolinearitas pada langkah 2. Ketika antar variabel penelitian tidak terjadi multikolinearitas, maka dilakukan perhitungan jarak objek dengan metode Euclidean. Sedangkan variabel penelitian terjadi multikolinearitas dilakukan perhitungan jarak objek dengan metode Mahalanobis;

5. menyajikan dendogram dan hasil cluster menggunakan metode terbaik;

6. melakukan profilisasi setiap cluster untuk mengetahui karakteristik dari setiap cluster. 


\section{HASIL DAN PEMBAHASAN}

\section{Analisis Deskriptif}

Sebagai langkah awal dari penelitian ini disajikan gambaran kasus kemiskinan yang terjadi di Indonesia dari 2015-2020, pada Gambar 1 disajikan visualisasi PPM.

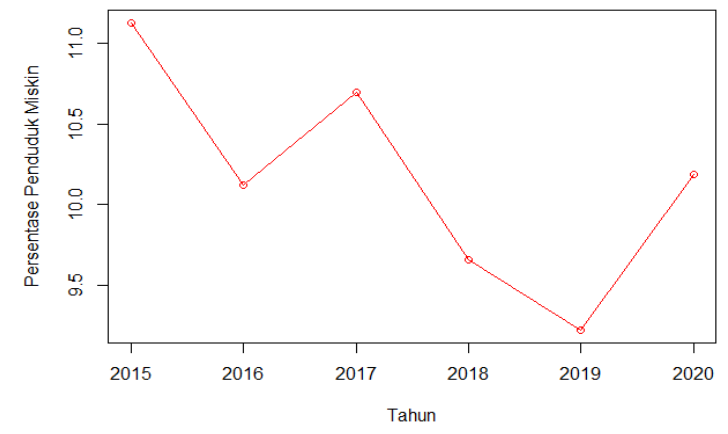

Gambar 1. Visualisasi Persentase Penduduk Miskin Indonesia 2015-2020

Berdasarkan Gambar 1 PPM Indonesia menunjukkan pergerakan yang fluktuatif dari 2015 hingga 2017, namun terjadi penurunan hingga tahun 2019. Menurut Bappenas, terdapat tiga faktor yang mempengaruhi penurunannya dengan salah satunya adalah pelaksanaan program pengentasan kemiskinan. Namun pada tahun 2020 PPM mengalami peningkatan sebagai akibat dari pandemi Covid-19. Menurut BPS, tercatat di Indonesia pada Maret 2020 sebanyak 26,42 juta jumlah penduduk miskin sehingga tingkat kemiskinan dari total populasi nasional sebesar 9,78\%. Peningkatan jumlah penduduk miskin terjadi karena penurunan pendapatan masyarakat sebagai akibat dari kebijakan pemerintah dalam upaya penanganan pandemi Covid-19.

Selanjutnya mengeksplorasi masing-masing variabel pada tiap provinsi. Eksplorasi dilakukan dengan analisis deskriptif berupa nilai minimum dan nilai maksimum dari setiap variabel dalam penelitian disajikan pada Tabel 2.

Tabel 2. Analisis Deskriptif

\begin{tabular}{|c|c|c|}
\hline Variabel & Nilai Minimum & Nilai Maksimum \\
\hline Harapan Lama Sekolah (HLS) (tahun) & 11.08 & 15.59 \\
\hline Angka Melek Huruf (AMH) (\%) & 77.79 & 99.53 \\
\hline Rata-rata Lama Sekolah (RLS) (tahun) & 6.69 & 11.13 \\
\hline Indeks Keparahan Kemiskinan (P2) & 0.11 & 2.24 \\
\hline Persentase Penduduk Miskin (PPM) (\%) & 3.78 & 26.64 \\
\hline Tingkat Pengangguran Terbuka (TPT) (\%) & 3.32 & 10.95 \\
\hline Indeks Kedalaman Kemiskinan (P1) & 0.57 & 6.53 \\
\hline
\end{tabular}

Tabel 2 menyajikan informasi tentang nilai minimum dan maksimum masing-masing variabel pada provinsi di Indonesia. Nilai HLS, AMH, dan RLS minimum terjadi di Provinsi Papua. Hal tersebut mengindikasikan buruknya kualitas pendidikan di Provinsi Papua. Penelitian yang dilakukan oleh Parwa dan Yasa (2019) menyatakan bahwa pendidikan memiliki pengaruh dalam pengurangan angka kemiskinan. Kualitas pendidikan yang rendah tentunya akan membuat produktivitas yang rendah, sehingga akan sulit membuka peluang mendapat pekerjaan yang lebih layak atau pada keadaan ini menyebabkan pendapatan masyarakat yang rendah. Hal tersebut didukung dengan nilai persentase penduduk miskin di Provinsi Papua yang merupakan angka tertinggi di Indonesia.

Nilai P2, PPM, dan P1 minimum terjadi provinsi Bali. Hal tersebut menggambarkan kondisi kemiskinan di provinsi Bali cukup rendah. Laporan perekonomian provinsi Bali oleh Bank Indonesia februari 2021 memperkirakan membaiknya pertumbuhan ekonomi pada triwulan II 2021. Membaiknya pertumbuhan ekonomi yang diprediksi tentunya akan membawa perubahan berupa semakin berkurangnya kemiskinan di provinsi Bali.

\section{Uji Multikolinearitas}

Uji multikolinearitas dilakukan untuk mengetahui hubungan linear diantara beberapa atau semua variabel penelitian yang digunakan. Pendeteksian terjadinya gejala multikolinearitas dapat dilakukan dengan berbagai cara diantaranya yang akan digunakan penelitian ini adalah menggunakan nilai variance inflating factor (VIF). 
Terjadinya gejala multikolinieritas adalah ketika nilai VIF lebih dari 10. Apabila terjadi multikolinearitas, maka dilakukan pengukuran jarak dengan menggunakan metode jarak Mahalanobis. Sedangkan jika tidak terjadi multikolinearitas perhitungan jarak dilakukan menggunakan metode jarak Euclidean.

1. Hipotesis

$\mathrm{H}_{0}$ : Tidak Terdapat Multikolinearitas

$\mathrm{H}_{1}$ : Terdapat Multikolinearitas

2. Tk.Signifikansi

$\alpha=5 \%=0.05$

3. Daerah Kritis

Tolak $\mathrm{H}_{0}$ jika VIF $\geq 10$

4. Stat.Uji dan Keputusan

Tabel 3. Variabel, VIF, Tanda, Daerah Kritis (DK), dan Keputusan Untuk Uji Multikolinearitas

\begin{tabular}{|c|c|c|c|c|c|}
\hline \multicolumn{2}{|c|}{ Variabel } & \multirow{2}{*}{$\begin{array}{c}\text { VIF } \\
2.128475\end{array}$} & \multirow{2}{*}{$\begin{array}{c}\text { Tanda } \\
<\end{array}$} & \multirow{2}{*}{$\begin{array}{c}\text { DK } \\
10\end{array}$} & \multirow{2}{*}{$\frac{\text { Keputusan }}{{\text { Gagal Tolak } \mathrm{H}_{0}}}$} \\
\hline HLS & AMH & & & & \\
\hline & $\mathrm{P} 2$ & 9.996757 & $<$ & 10 & Gagal Tolak $\mathrm{H}_{0}$ \\
\hline & PPM & 7.563147 & $<$ & 10 & Gagal Tolak $\mathrm{H}_{0}$ \\
\hline & TPT & 1.645480 & $<$ & 10 & Gagal Tolak $\mathrm{H}_{0}$ \\
\hline & RLS & 1.991929 & $<$ & 10 & Gagal Tolak $\mathrm{H}_{0}$ \\
\hline & $\mathrm{P} 1$ & 1.981776 & $<$ & 10 & Gagal Tolak $\mathrm{H}_{0}$ \\
\hline \multirow[t]{6}{*}{$\mathrm{AMH}$} & HLS & 1.836127 & $<$ & 10 & Gagal Tolak $\mathrm{H}_{0}$ \\
\hline & $\mathrm{P} 2$ & 10.254226 & $>$ & 10 & Tolak $\mathrm{H}_{0}$ \\
\hline & PPM & 8.807099 & $<$ & 10 & Gagal Tolak $\mathrm{H}_{0}$ \\
\hline & TPT & 1.786820 & $<$ & 10 & Gagal Tolak $\mathrm{H}_{0}$ \\
\hline & RLS & 2.609525 & $<$ & 10 & Gagal Tolak $\mathrm{H}_{0}$ \\
\hline & $\mathrm{P} 1$ & 1.949816 & $<$ & 10 & Gagal Tolak $\mathrm{H}_{0}$ \\
\hline \multirow[t]{6}{*}{$\mathrm{P} 2$} & HLS & 1.794639 & $<$ & 10 & Gagal Tolak $\mathrm{H}_{0}$ \\
\hline & $\mathrm{AMH}$ & 2.136043 & $<$ & 10 & Gagal Tolak $\mathrm{H}_{0}$ \\
\hline & PPM & 2.333260 & $<$ & 10 & Gagal Tolak $\mathrm{H}_{0}$ \\
\hline & $\mathrm{TPT}$ & 1.711276 & $<$ & 10 & Gagal Tolak $\mathrm{H}_{0}$ \\
\hline & RLS & 2.670968 & $<$ & 10 & Gagal Tolak $\mathrm{H}_{0}$ \\
\hline & $\mathrm{P} 1$ & 1.416589 & $<$ & 10 & Gagal Tolak $\mathrm{H}_{0}$ \\
\hline \multirow[t]{6}{*}{ PPM } & HLS & 1.673705 & $<$ & 10 & Gagal Tolak $\mathrm{H}_{0}$ \\
\hline & AMH & 2.259306 & $<$ & 10 & Gagal Tolak $\mathrm{H}_{0}$ \\
\hline & P2 & 2.876217 & $<$ & 10 & Gagal Tolak $\mathrm{H}_{0}$ \\
\hline & TPT & 1.727785 & $<$ & 10 & Gagal Tolak $\mathrm{H}_{0}$ \\
\hline & RLS & 2.592530 & $<$ & 10 & Gagal Tolak $\mathrm{H}_{0}$ \\
\hline & $\mathrm{P} 1$ & 1.889347 & $<$ & 10 & Gagal Tolak $\mathrm{H}_{0}$ \\
\hline \multirow{6}{*}{$\mathrm{TPT}$} & HLS & 1.784500 & $<$ & 10 & Gagal Tolak $\mathrm{H}_{0}$ \\
\hline & $\mathrm{AMH}$ & 2.246315 & $<$ & 10 & Gagal Tolak $\mathrm{H}_{0}$ \\
\hline & $\mathrm{P} 2$ & 10.337751 & $>$ & 10 & Tolak $\mathrm{H}_{0}$ \\
\hline & PPM & 8.467147 & $<$ & 10 & Gagal Tolak $\mathrm{H}_{0}$ \\
\hline & RLS & 1.968999 & $<$ & 10 & Gagal Tolak $\mathrm{H}_{0}$ \\
\hline & $\mathrm{P} 1$ & 2.022363 & $<$ & 10 & Gagal Tolak $\mathrm{H}_{0}$ \\
\hline \multirow[t]{6}{*}{ RLS } & HLS & 1.438464 & $<$ & 10 & Gagal Tolak $\mathrm{H}_{0}$ \\
\hline & $\mathrm{AMH}$ & 2.184502 & $<$ & 10 & Gagal Tolak $\mathrm{H}_{0}$ \\
\hline & $\mathrm{P} 2$ & 10.744246 & $>$ & 10 & Tolak $\mathrm{H}_{0}$ \\
\hline & PPM & 8.460043 & $<$ & 10 & Gagal Tolak $\mathrm{H}_{0}$ \\
\hline & TPT & 1.311133 & $<$ & 10 & Gagal Tolak $\mathrm{H}_{0}$ \\
\hline & $\mathrm{P} 1$ & 2.029073 & $<$ & 10 & Gagal Tolak $\mathrm{H}_{0}$ \\
\hline \multirow[t]{6}{*}{$\mathrm{P} 1$} & HLS & 1.894950 & $<$ & 10 & Gagal Tolak $\mathrm{H}_{0}$ \\
\hline & $\mathrm{AMH}$ & 2.161238 & $<$ & 10 & Gagal Tolak $\mathrm{H}_{0}$ \\
\hline & $\mathrm{P} 2$ & 7.545172 & $<$ & 10 & Gagal Tolak $\mathrm{H}_{0}$ \\
\hline & PPM & 8.163537 & $<$ & 10 & Gagal Tolak $\mathrm{H}_{0}$ \\
\hline & TPT & 1.783110 & $<$ & 10 & Gagal Tolak $\mathrm{H}_{0}$ \\
\hline & RLS & 2.686678 & $<$ & 10 & Gagal Tolak $\mathrm{H}_{0}$ \\
\hline
\end{tabular}


5. Kesimpulan

Dengan tingkat kepercayaan 95\%, pada pengujian variabel AMH, TPT, dan RLS menunjukkan adanya multikolinearitas pada variabel P2, sedangkan variabel lainnya menunjukkan tidak adanya multikolinearitas.

Berdasarkan pengujian multikolinearitas yang telah dilakukan, terdapat beberapa variabel yang menunjukkan adanya multikolinearitas. Sehingga perhitungan jarak untuk analisis cluster akan dilakukan dengan metode Mahalanobis.

\section{Penentuan Metode Cluster Terbaik}

Penentuan metode cluster terbaik dilakukan dengan membandingkan nilai koefisien agglomerative. Koefisien agglomerative mengukur jumlah struktur pengelompokan yang ditemukan, nilai yang mendekati 1 menunjukkan struktur pengelompokkan yang kuat. Tabel 4 merupakan hasil perhitungan koefisien agglomerative.

Tabel 4. Koefisien Agglomerative

\begin{tabular}{cc}
\hline & Koefisien Agglomerative \\
\hline Average & 0.9697 \\
Single & 0.9524 \\
Complete & 0.9768 \\
Ward & 0.9850 \\
\hline
\end{tabular}

Pada Tabel 4, hasil perhitungan koefisien agglomerative menunjukkan bahwa metode yang memiliki koefisien agglomerative paling tinggi adalah metode ward yaitu sebesar 0.985 . Sehingga pengelompokkan kemiskinan di Indonesia akan menggunakan hierarchical clustering dengan metode ward.

\section{Hasil Metode Cluster Terbaik}

Analisis clustering dengan metode ward dibentuk menjadi 3 cluster yaitu tinggi, sedang dan rendah dan disajikan dalam bentuk dendogram. Gambar 2 merupakan penyajian dendogram clustering data kemiskinan di Indonesia tahun 2020.

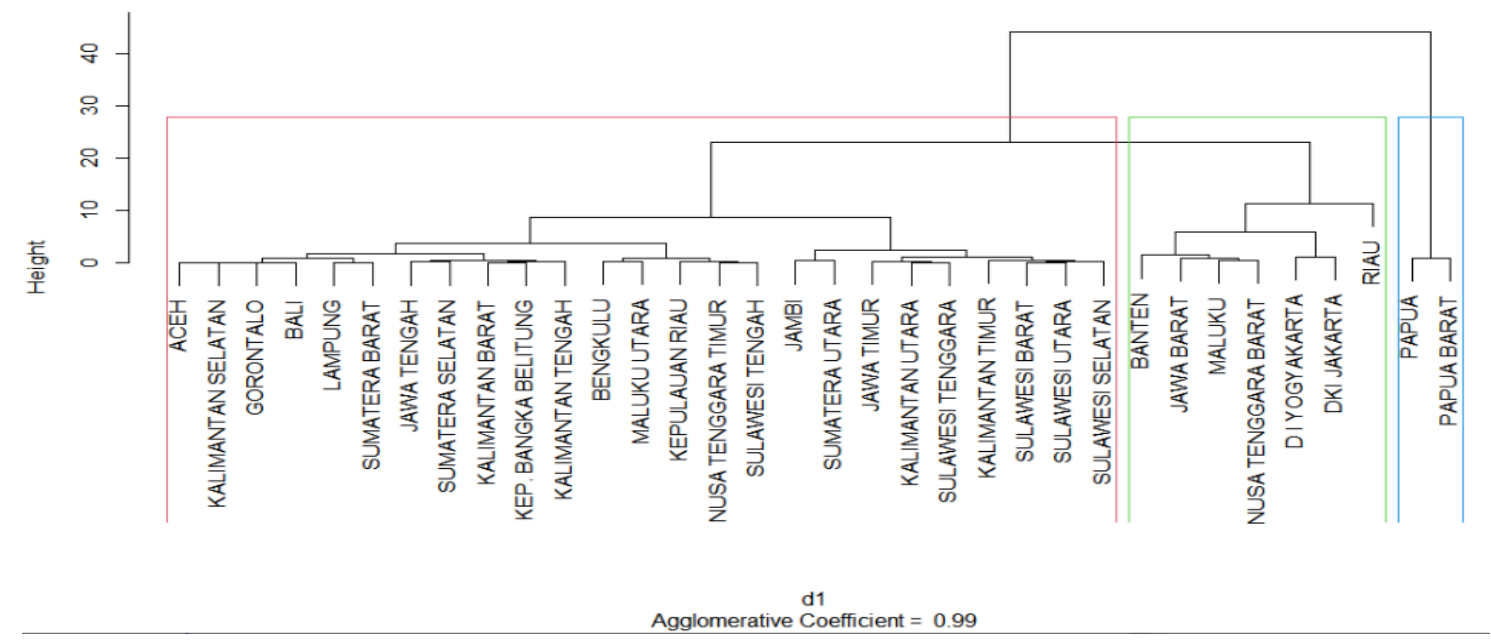

Gambar 2. Dendogram Hasil Clustering

Provinsi di Indonesia berhasil dilakukan clustering menjadi 3 cluster yang memiliki tingkatan tinggi, sedang, dan rendah. Tampilan provinsi hasil clustering yang lebih sederhana dapat dilihat pada Tabel 5. 
Tabel 5. Provinsi Hasil Clustering

\begin{tabular}{|c|c|c|}
\hline Cluster & Anggota & Jumlah Anggota \\
\hline $\mathbf{1}$ & $\begin{array}{c}\text { Aceh, Kalimantan Selatan, Gorontalo, Bali, Lampung, Sumatera Barat, Jawa } \\
\text { Tengah, Sumatera Selatan, Kalimantan Barat, Kep. Bangka Belitung, } \\
\text { Kalimantan Tengah, Bengkulu, Maluku Utara, Kepulauan Riau, Nusa Tenggara } \\
\text { Timur, Sulawesi Tengah, Jambi, Sumatera Utara, Jawa Timur, Kalimantan } \\
\text { Utara, Sulawesi Tenggara, Kalimantan Timur, Sulawesi Barat, Sulawesi Utara, } \\
\text { Sulawesi Selatan }\end{array}$ & 25 \\
\hline 2 & $\begin{array}{c}\text { Banten, Jawa Barat, Maluku, Nusa Tenggara Barat, DI Yogyakarta, DKI Jakarta, } \\
\text { dan Riau }\end{array}$ & 7 \\
\hline 3 & Papua dan Papua Barat & 2 \\
\hline
\end{tabular}

\section{Karakteristik Cluster}

Masing-masing anggota cluster yang telah diperoleh selanjutnya dilakukan profilisasi untuk mengetahui karakteristik dari masing-masing cluster dengan cara mencari rata-rata masing-masing variabel pada tiap cluster.

Tabel 6. Profilisasi

\begin{tabular}{ccccccccc}
\hline Cluster & HLS & AMH & RLS & P2 & PPM & TPT & P1 & Keterangan \\
\hline 1 & 13.112 & 98.658 & 8.611 & 0.425 & 9.506 & 5.573 & 1.665 & Rendah \\
2 & 13.546 & 98.556 & 9.214 & 0.467 & 9.834 & 7.819 & 1.971 & Sedang \\
3 & 11.995 & 88.100 & 7.145 & 2.225 & 24.005 & 5.540 & 5.310 & Tinggi \\
\hline
\end{tabular}

Pada Tabel 6 diberi tanda bahwa nilai terbesar setiap variabel berwarna merah, nilai sedang warna orange, dan nilai terkecil berwarna hijau, kemudian diberikan interpretasi sebagai berikut:

1) Cluster 1 dicirikan oleh AMH yang paling tinggi, serta P2, P1, dan PPM yang paling rendah dibandingkan cluster lainnya. Hal ini mengindikasikan kemiskinan cluster ini menunjukkan ketimpangan pengeluaran yang menyempit, rata-rata pengeluaran, dan jumlahnya diatas garis kemiskinan. Pada keadaan ini pemerintah dapat mempertahankan kestabilan perekonomian.

2) Cluster 2 dicirikan oleh HLS, RLS, dan TPT paling tinggi dibandingkan cluster lain. Hal tersebut mengindikasikan kualitas pendidikan yang cukup baik dalam mendukung pengurangan angka kemiskinan, meskipun masih tingginya nilai TPT. Dalam mengatasi TPT yang masih tinggi, maka pemerintah dapat lebih menggalakkan informasi pelatihan kerja ke masyarakat, sehingga tercipta tenaga kerja terampil yang dapat bersaing bahkan dapat menciptakan lapangan pekerjaan.

3) Cluster 3 dicirikan oleh P2, PPM, dan P1 yang paling tinggi, selain itu HLS, AMH, dan RLS yang paling rendah dibandingkan cluster lainnya. Hal tersebut mengindikasikan parahnya tingkat kemiskinan karena tingginya P2, PPM, dan P1, serta rendahnya kualitas pendidikan. Maka pemerintah dapat membuat kebijakan pada daerah Cluster 3 berupa peningkatan sarana dan prasarana pendidikan seperti pembangunan sekolah unggulan di kota maupun pedalaman untuk meningkatkan nilai HLS, AMH dan RLS. Hal tersebut diharapkan dapat memperbaiki perekonomian di Cluster 3 dan mengurangi tingkat kemiskinannya.

\section{KESIMPULAN}

Berdasarkan hasil penelitian dan pembahasan yang telah diuraikan, maka peneliti memperoleh beberapa kesimpulan terkait kondisi kemsikinan di Indonesia pada tahun 2020. Tingkat kemiskinan tertinggi berada di provinsi Papua dengan nilai HLS, AMH, dan RLS yang sangat rendah. Sedangkan provinsi Bali dengan tingkat kemiskinan yang cukup rendah dengan nilai P2, PPM, dan P1 yang sangat kecil.

Pengelompokkan provinsi berdasarkan kemiskinan di Indonesia dilakukan dengan mentode terbaik setelah membandingkan nilai koefisien agglomerative yaitu metode ward. Hasil clustering terbentuk 3 cluster dengan cluster 1 sebanyak 25 provinsi dengan tingkat kemiskinan rendah, cluster 2 sebanyak 7 provinsi dengan tingkat kemiskinan sedang, dan cluster 3 sebanyak 2 provinsi dengan tingkat kemiskinan tinggi. Cluster 1 merupakan cluster dengan kemiskinan yang rendah karena memiliki nilai rata-rata P2, P1, dan PPM yang rendah dan nilai rata-rata $\mathrm{AMH}$ yang tinggi. Cluster 2 merupakan cluster dengan kemiskinan yang sedang. 
Provinsi di Cluster 2 memiliki nilai rata-rata HLS dan RLS yang tinggi dan memiliki rata-rata pengangguran yang tinggi. Cluster 3 merupakan cluster dengan kemiskinan yang tinggi karena memiliki nilai rata-rata P2, P1, dan PPM yang tinggi, serta memiliki nilai rata-rata TPT yang rendah. Selain itu Cluster 3 memiliki nilai rata-rata HLS, AMH, dan RLS terendah.

\section{DAFTAR PUSTAKA}

BPS. (2020). Keadaan Ketenagakerjaan Indonesia Agustus 2020. Jakarta: Berita Resmi Statistik Badan Pusat Statistik.

Bullard J, D. K. (2020). Predicting infectious SARS-CoV-2 from diagnostic samples. Clinical Infectious Diseases (pp. 2663-2666). New York: Oxford University Press.

Dani, A. T., Wahyuningsih, S., \& Rizki, N. A. (2019). Penerapan Hierarchical Clustering Metode Agglomerative pada Data Runtun Waktu. Jambura Journal of Mathematics, 66.

Fajriani. (2019). Persebaran Tingkat Kemiskinan di Sulawesi Selatan Menggunakan K-Means Clustering Analysis. SEMANTIIK, 276-281.

Febuariyanti, H., \& Winarko, E. (2010). Klastering Dokumen Menggunakan Hierarchical Agglomerative Clustering. Prosiding Seminar Nasional Sistem dan Teknologi Informasi (SNASTI).

Ferezagia, D. V. (2018). Analisis Tingkat Kemiskinan di Indonesia. Jurnal Sosial Humaniora Terapan, 1, 1-6. doi:https://doi.org/10.7454/jsht.v1i1.6

Ningrat, D. R., Maruddani, D. A., \& Wuryandari, T. (2016). Analisis Cluster Dengan Algoritma K-Means dan Fuzzy C-Means Clustering Untuk Pengelompokkan Data Obligasi Korporasi. Jurnal Gaussian, 641-650.

Oktavia, S. d. (2013). Pengelompokan Kinerja Dosen Jurusan Matematika FMIPA UNTAN berdasarkan Penilaian Mahasiswa Menggunakan Metode Ward's. Buletin Ilmiah Mat. Stat. dan Terapannya (Bimaster), 93-100.

Parwa, I., \& Yasa, I. (2019). Pengaruh Tingkat Pendidikan Dan Investasi Terhadap Pertumbuhan Ekonomi Dan Kemiskinan Di Provinsi Bali. E-Jurnal EP Unud, 945-973.

Prabowo, R. A., Nisa, K., Faisol, A., \& Setiawan, E. (2020). Simulasi Pemilihan Metode Analisis Cluster Hirarki Agglomerative Terbaik Antara Average Linkage dan Ward pada Data yang Mengandung Masalah Multikolinearitas. Siger Matematika, 49-55.

Rahmawati, L. A. (2013). Analisis Kelompok dengan Menggunakan Metode Hierarki untuk Pengelompokan Kabupaten/Kota di Jawa Timur Berdasar Indikator Kesehatan. Matematika FMIPA Universitas Negeri Malang.

Royat, S. (2015). Kebijakan Pemerintah dalam Penangulangan Kemiskinan. Jakarta: Menko Kesra Bidang Koordinasi Pengangulan Kemiskinan.

Salton, G. (1989). Automatic text processing: the transformation, analysis, and retrieval of information by computer. United States: Addison-Wesley Longman Publishing Co., Inc.

Wahyuningsih, S., Rizki, N. A., \& Dani, A. T. (2019). Penerapan Hierarchical Clustering Metode Agglomerative Pada Data Runtun Waktu. Jambura Journal of Mathematics, 64-78.

Widyawati, Saptomo, W. L., \& Utami, Y. R. (2020). Penerapan Agglomerative Hierarchical Clustering Untuk Segmentasi Pelanggan. Jurnal Ilmiah Sinus (JIS), 75-87. 